\title{
IMPLEMENTASI APLIKASI HARGA POKOK PRODUKSI PADA UKM
}

\author{
Vini Mariani ${ }^{1}$; Lianawati Christian² ${ }^{2}$ Henny Hendarti ${ }^{3}$ \\ 1, 2,3 Information Systems Department, School of Information Systems, BINUS University \\ Jl.KH.Syahdan no.9 Kemanggisan Palmerah Jakarta Indonesia \\ 1vmariani@binus.edu; ${ }^{2}$ liana_ch1309@binus.ac.id; ’henny@binus.edu
}

\begin{abstract}
The accuracy of the production cost report is the basis of the control and decision making. Production cost affects the selling price of a product. The purpose of the study is to examine the procedures, forms, and reports relating to accounting information system production cost calculation in SMEs, analyze and design information systems that can support the planning and control of production information system ranging from production planning to report the cost of production by using The weighted average method. The methodology used is the method of data collection, information and interviews. The method of designing the production cost is Object Oriented and Design. Program language used is Visual Basic. Implementation of the production cost applications in small and medium enterprises (SMEs) is to make application of MO estimation recording process and MO rate, cost card standard recording, WIP process recording, the quotation letter of raw materials, receipt of goods recording, the working hours card recording, cash expenditures recording, WIP transfer unit recording (work in process), the process of the final WIP units recording.
\end{abstract}

Keywords: application, final production price, implementation, SME

\begin{abstract}
ABSTRAK
Keakuratan laporan harga pokok produksi merupakan dasar dalam pengendalian dan pengambilan keputusan. Harga pokok produksi mempengaruhi harga jual suatu produk. Tujuan penelitian adalah meneliti terhadap prosedur, formulir, dan laporan yang berhubungan dengan sistem informasi akuntansi perhitungan harga pokok produksi pada UKM, menganalisis dan merancang sistem informasi yang dapat mendukung perencanaan dan pengendalian sistem informasi produksi mulai dari perencanaan produksi sampai dengan laporan harga pokok produksi dengan menggunakan metode rata-rata tertimbang. Metodologi yang digunakan adalah metode pengumpulan data, informasi dan Wawancara. Metode perancangan harga pokok produksi adalah Object Oriented and Design. Bahasa program yang digunakan adalah Visual Basic. Implementasi aplikasi harga pokok produksi pada Usaha Kecil Menengah (UKM) membuat aplikasi mengenai proses pencatatan estimasi MO dan MO rate, pencatatan standar cost card, pencatatan WIP Proses, pembuatan surat permintaan bahan baku, pencatatan penerimaan barang, pencatatan kartu jam kerja, pencatatan pengeluaran kas, pencatatan transfer unit WIP (Work In Process), proses pencatatan unit WIP akhir.
\end{abstract}

Kata kunci: aplikasi, harga pokok produksi, implementasi, UKM 


\section{PENDAHULUAN}

Pada bidang produksi, faktor yang perlu mendapat perhatian dan dukungan dalam pengelolaannya dalam upaya mencapai tujuan operasional secara optimal.

"Production systems are becoming more and more information intensive activities. Production management is faced with new challenges which demand an overall information approach to production information systems planning. However, production systems are not all alike. Each system presents different information implications for system selection and operation”. (Boggs, 1987).

Aktivitas yang dilakukan pada proses produksi antara lain memproduksi dan mendistribusikan produk yang dihasilkan dan menciptakan nilai tambah produk yang merupakan output dari setiap industri. Perkembangan teknologi sangat mempengaruhi perkembangan produksi. Dengan berkembangnya teknologi maka kegiatan produksi juga semakin berkembang. Demikian pula dengan kegiatan usaha kecil dan menengah, untuk dapat berkompetisi maka peran teknologi juga sangat dibutuhkan.

"Today, to improve productivity in manufacturing, one has a large variety of improvement programmes at one's disposal. Zero defects, value analysis, just-intime, manufacturing lead time reduction are just a few of a long list of potential action programmes", (Meyer dan Ferdows, 1990).

Peran teknologi dalam menunjang kegiatan proses produksi diharapkan dapat meningkatkan kualitas dan produktivitas sehingga proses kegiatan produksi menjadi efektif dan efisien. Perhitungan harga pokok produksi pada kegiatan produksi merupakan salah satu hal yang sangat penting. Keakuratan perhitungan harga pokok produksi menghasilkan laporan harga pokok produksi yang akurat. Hal ini merupakan suatu dasar yang sangat diperlukan dalam pengendalian dan pengambilan keputusan. "Argues that a proper costing system is an important part of establishing a productivity measurement and control system and is the basis of effective planning and decision making" (Sedgewick, 1992).

Hal ini disebabkan harga pokok produksi berpengaruh terhadap harga jual suatu produk. Dengan perhitungan harga pokok yang tidak akurat menimbulkan ketidakakuratan dalam menentukan harga jual, dan hal ini mempengaruhi UKM dalam bersaing dengan UKM lain yang mempunyai harga jual yang lebih rendah. Bila harga pokok produksi dihitung lebih rendah dibandingkan dengan biaya aktual yang terjadi, maka ini akan menimbulkan kerugian bagi UKM.

Ruang lingkup penelitian ini adalah penelitian terhadap prosedur, formulir, dan laporan yang digunakan oleh UKM. Prosedur, formulir, dan laporan tersebut terkait dengan perhitungan harga pokok produksi, menganalisis dan merancang sistem informasi yang dapat mendukung kegiatan produksi. Kegiatan produksi ini dimulai dari perencanaan produksi sampai dengan perhitungan harga pokok produksi dengan menggunakan sistem perhitungan biaya produksi berdasarkan proses (Process costing) dan metode rata-rata tertimbang (Weighted-average method).

Penelitian ini bertujuan untuk: (1) Meneliti terhadap prosedur, formulir, dan laporan yang digunakan oleh UKM terkait dengan perhitungan harga pokok produksi. (2) Menganalisis dan merancang sistem informasi mulai dari perencanaan produksi sampai dengan laporan harga pokok produksi. (3) Menggunakan sistem perhitungan biaya produksi berdasarkan proses (Process costing) dan metode rata-rata tertimbang (Weighted-average method) dalam pembuatan laporan biaya produksi. 


\section{Definisi Informasi}

Informasi seperti darah yang mengalir di dalam tubuh suatu organisasi, sehingga informasi ini sangat penting dalam organisasi. Informasi adalah data yang diolah menjadi bentuk yang lebih berarti bagi yang menerimanya. (Jogiyanto, 2005). Jadi informasi adalah data yang telah diolah dan dapat digunakan oleh pemakai untuk mengambil keputusan. Informasi harus dikelola dengan baik agar dapat memberi manfaat yang maksimal. Penerapan sistem informasi pada suatu organisasi ditujukan untuk memberikan dukungan informasi yang dibutuhkan, khususnya oleh para pengguna informasi dari berbagai tingkatan manajemen. Dengan semakin berkembangnya dunia teknologi, sistem informasi yang digunakan lebih berfokus pada sistem informasi berbasis komputer. Harapan yang ingin diperoleh dengan penggunaan teknologi maka menghasilkan informasi yang akurat, berkualitas dan tepat waktu.

\section{Pengertian Sistem, Informasi dan Sistem Informasi}

Menurut O'Brien (2005), sistem adalah sekelompok komponen yang saling berhubungan, berkerjasama untuk mencapai tujuan bersama dengan menerima input serta menghasilkan output dalam proses transformasi yang teratur. Sedangkan menurut Romney dan Steinbart (2006), sistem adalah suatu kumpulan dari dua atau lebih komponen yang saling ketergantungan dan berinteraksi untuk mencapai suatu tujuan. Berdasarkan definisi di atas dapat disimpulkan bahwa sistem adalah sekumpulan komponen, function dan interface yang saling terintegerasi dengan menerima input dan menghasilkan output untuk mencapai tujuan.

O’Brien (2005) mendefinisikan informasi sebagai data yang telah diubah menjadi konteks yang berarti dan berguna bagi pemakai akhir tertentu. Menurut Romney dan Steinbart (2006), informasi adalah data yang telah diorganisasikan dan diproses untuk menyediakan arti bagi pengguna. Berdasarkan definisi di atas dapat disimpulkan bahwa informasi adalah data yang sudah diolah sehingga memiliki arti bagi pengguna untuk pengambilan keputusan.

Menurut Whitten, Bentley dan Dittman (2009), "Information system an arrangement of people, data, processes, and information technology interact to collect, process, store and provide as output the information needed to support an organization”. Jadi, sistem informasi adalah pengaturan orang, data, proses, dan teknologi informasi yang berinteraksi untuk mengumpulkan, memproses, menyimpan, dan menyediakan output berupa informasi yang diperlukan untuk mendukung sebuah organisasi”.

Menurut O'Brien (2005) "Information system is an information can be any organized combination of people, hardware, software, communications network, and data resources that collects, transform and disseminates information in an organization”. Jadi, sistem informasi dapat berupa kombinasi dari manusia, perangkat keras, piranti lunak, jaringan komunikasi dan data yang mengumpulkan, mengolah dan mendistribusikan informasi dalam sebuah organisasi. Berdasarkan pendapat-pendapat di atas dapat disimpulkan bahwa sistem informasi adalah sebuah rangkaian dari manusia, perangkat keras, piranti lunak, jaringan komunikasi dan data yang dikumpulkan dan didistribusikan kepada pemakai.

\section{Tujuan dan Kegunaan Sistem Informasi Akuntansi}

Menurut Romney dan Steinbart (2006), kerjasama dari keenam komponen sistem informasi sebagaimana yang telah disebutkan diatas memungkinkan sistem informasi akuntansi untuk memenuhi tiga fungsi bisnis yang penting yaitu: (1) Mengumpulkan dan menyimpan data mengenai aktivitas organisasi, sumber daya dan personel. (2) Mengubah data menjadi informasi yang berguna untuk pengambilan keputusan sehingga manajemen dapat merencanakan, melaksanakan, mengendalikan, 
dan mengevaluasi aktivitas, sumber daya, dan personel. (3) Menyediakan pengendalian yang memadai untuk melindungi asset organisasi, termasuk datanya, untuk menjamin bahwa asset dan data tersedia ketika dibutuhkan dan datanya akurat dan dapat diandalkan.

Selain itu Romney \& Steinbart (2006) juga mengemukakan bahwa sebuah sistem informasi akuntansi yang dirancang dengan baik dapat meningkatkan kualitas dan menurunkan biaya dari barang dan jasa, meningkatkan efisiensi, berbagi pengetahuan, meningkatkan efisiensi dan efektivitas dari supply chain-nya, meningkatkan struktur pengendalian internal, meningkatkan pembuatan keputusan.

\section{Siklus Hidup dan Strategi Produk}

Menurut Heizer dan Render (2006), ada beberapa pilihan stategi saat produk berjalan melintasi siklus hidup produk, yaitu: (1) Fase Perkenalan: penelitian, pengembangan produk, modifikasi dan perbaikan proses, dan pengembangan pemasok. (2) Fase Pertumbuhan: desain produk telah mulai stabil, dan diperlukan peramalan kebutuhan kapasitas yang efektif untuk menampung peningkatan permintaan produk mungkin diperlukan. (3) Fase Kematangan: pengendalian biaya yang lebih baik, berkurangnya pilihan dan pemotongan lini produk mungkin efektif atau diperlukan untuk meningkatkan keuntungan dan pangsa pasar. (4) Fase Penurunan: produk yang hampir mati biasanya produk yang buruk bagi investasi sumber daya dan kemampuan manajerial. Kecuali jika produk yang hampir mati ini membuat kontribusi yang unik bagi reputasi perusahaan atau lini produknya, atau bisa dijual dengan harga yang tinggi, maka produksi mereka harus dihentikan.

\section{Pengadaan Kebutuhan Material}

Sebelum proses produksi dilakukan perlu adanya pengadaan persediaan yang dibutuhkan untuk memproduksi produk. Persediaan dapat dibedakan atas beberapa tipe yaitu: (1) Supplies (persediaan bahan pembantu), yaitu barang persediaan yang diperlukan dalam proses produksi tetapi bukan merupakan bagian dari produk jadi. (2) Komponen, yaitu barang-barang yang terdiri atas bagian-bagian (parts) yang diperoleh dari perusahaan lain atau hasil produksi sendiri untuk digunakan dalam pembuatan barang jadi atau barang setengah jadi. (3) Raw materials (persediaan bahan mentah), yaitu barang persediaan yang dibeli atau dipasok dari supplier yang akan dijadikan sebagai masukan dalam proses produksi. (4) Work in process (persediaan barang dalam proses), yaitu persediaan barang yang merupakan keluaran dari suatu bagian proses produksi, namun masih perlu diolah atau diproses lebih lanjut lagi untuk menjadi produk jadi. (5) Finished goods (persediaan barang jadi), yaitu persediaan barang yang sudah diproses dan siap untuk dikirim ke pelanggan.

\section{Akuntansi Biaya}

"Accountants define cost as a resource sacrificed or forgone to achieve a specific objective. A cost (such as direct materials or advertising) is usually measured as the monetary amount that must be paid to acquire goods or services. An actual cost is the cost incurred (a historical or past cost), as distinguished from a budgeted cost, which is a predicted or forecasted cost (a future cost)”. (Horngren, 2012)

"Several factors affect the classification of a cost as direct or indirect: (1) The materiality of the cost in question. The smaller the amount of a cost-that is, the more immaterial the cost is-the less likely that it is economically feasible to trace that cost to a particular cost object. (2) Available information-gathering technology. Improvements in informationgathering technology make it possible to consider more and more costs as direct costs. (3) Design of operations. Classifying a cost as direct is easier if a company's facility is used exclusively for a specific cost object, such as a specific product or a particular customer". (Horngren, 2012) 
"A variable cost changes in total in proportion to changes in the related level of total activity or volume. A fixed cost remains unchanged in total for a given time period, despite wide changes in the related level of total activity or volume. Costs are defined as variable or fixed with respect to a specific activity and for a given time period". (Horngren, 2012).

\section{METODE}

Metode pengumpulan data dan informasi dilakukan melalui: (1) Studi pustaka (Library research), Teori-teori dan informasi yang dikumpulkan merupakan hasil pencarian dari buku-buku, jurnal ilmiah dan literatur yang berkaitan dengan topik penelitian. (2) Penelitian lapangan/ pengumpulan data dan observasi ke lapangan/ke UKM (Usaha Kecil Menengah). (3) Wawancara (Interview), Dilakukan Tanya jawab dengan pihak-pihak yang terkait untuk mendapatkan keterangan yang diperlukan.

Metode perancangan harga pokok produksi dengan menggunakan Object Oriented and Design (OOAD). Bahasa program yang digunakan adalah Visual Basic.

\section{Tahapan Penelitian:}

Adapun tahapan penelitian adalah sebagai berikut:

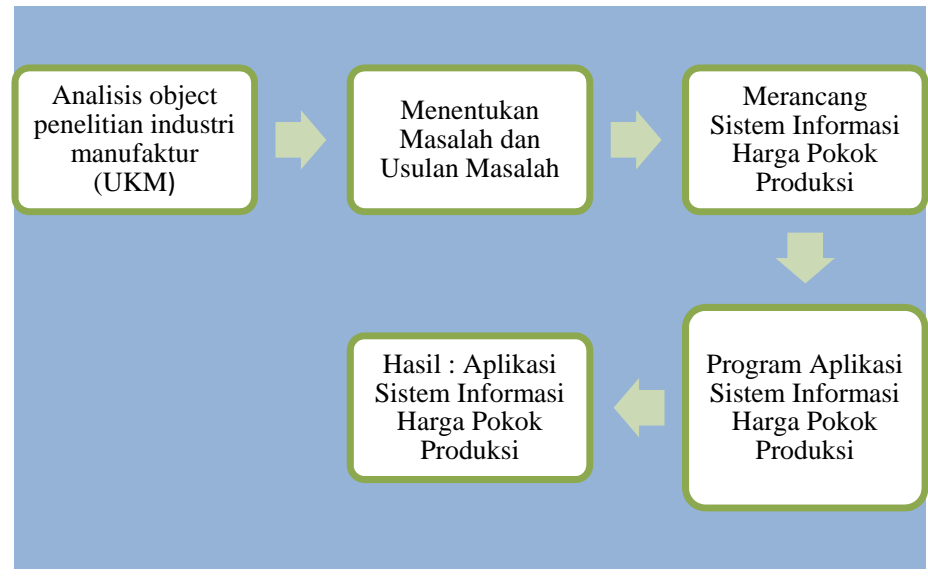

Gambar 1Tahapan Penelitian

\section{HASIL DAN PEMBAHASAN}

Hasil penelitian implementasi aplikasi harga pokok produksi pada Usaha Kecil Menengah (UKM) dapat dijelaskan tahapan-tahapan seperti dalam rich picture Proses Bisnis Harga Pokok Produksi pada UKM, UML Diagram, Rancangan Formulir, Rancangan Laporan dan Rancangan Layar di bawah ini. 


\section{Rich Picture}

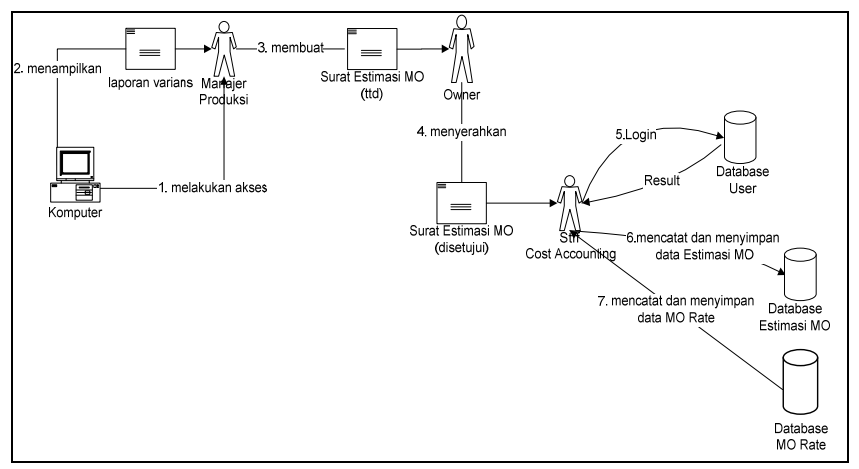

Gambar 2 Rich Picture Pencatatan Estimasi MO dan MO Rate

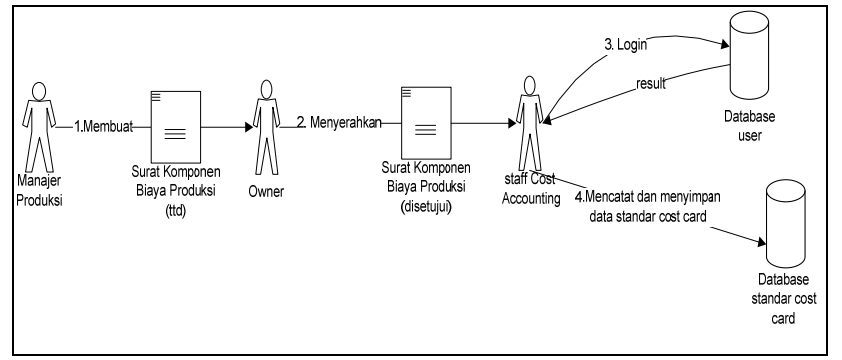

Gambar 3 Rich Picture Pencatatan Standar Cost Card

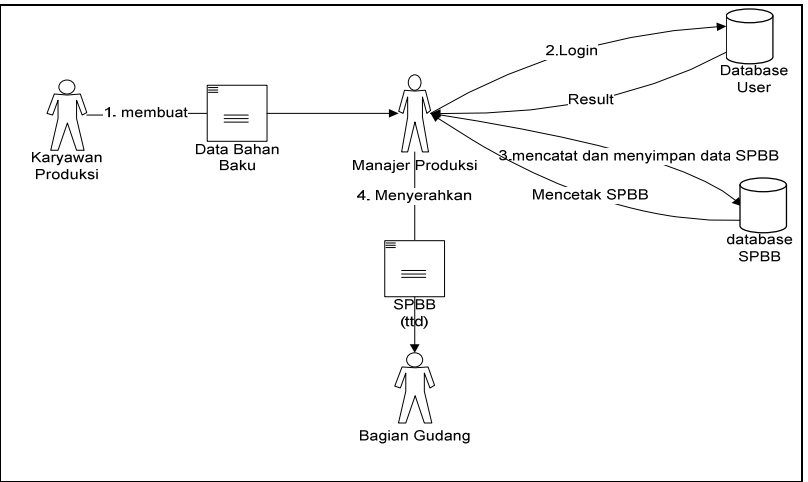

Gambar 5 Rich Picture pembuatan surat permintaan bahan baku

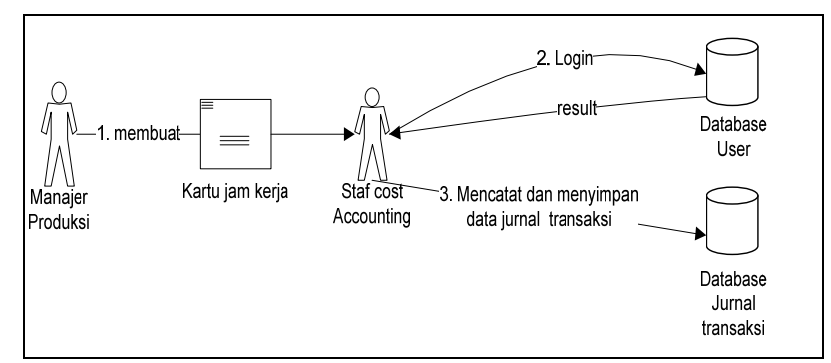

Gambar 7 Rich Picture pencatatan Kartu Jam Kerja

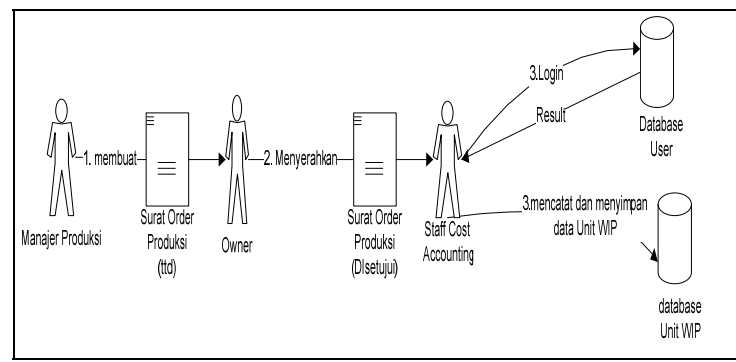

Gambar 4 Rich Picture Pencatatan WIP Proses

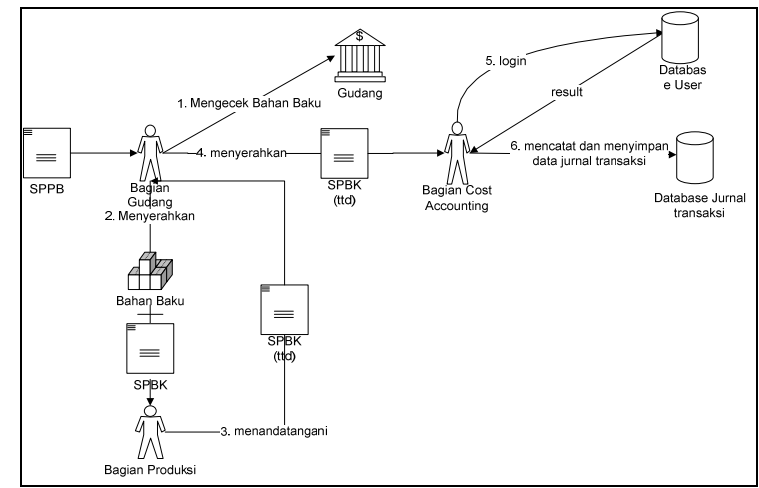

Gambar 6 Rich Picture Proses pencatatan penerimaan barang

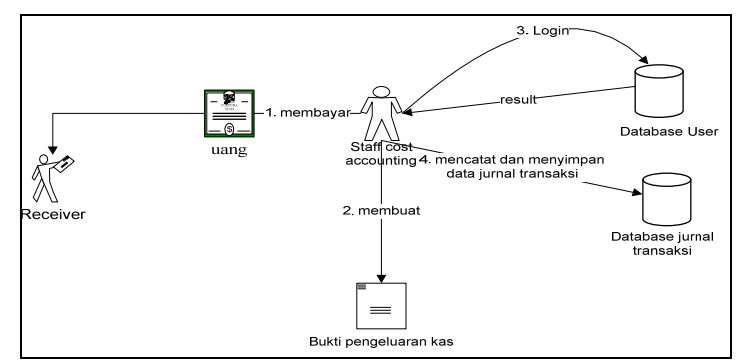

Gambar 8 Rich Picture Pencatatan Pengeluarkan Kas (Biaya Manafacturing Overhead) 


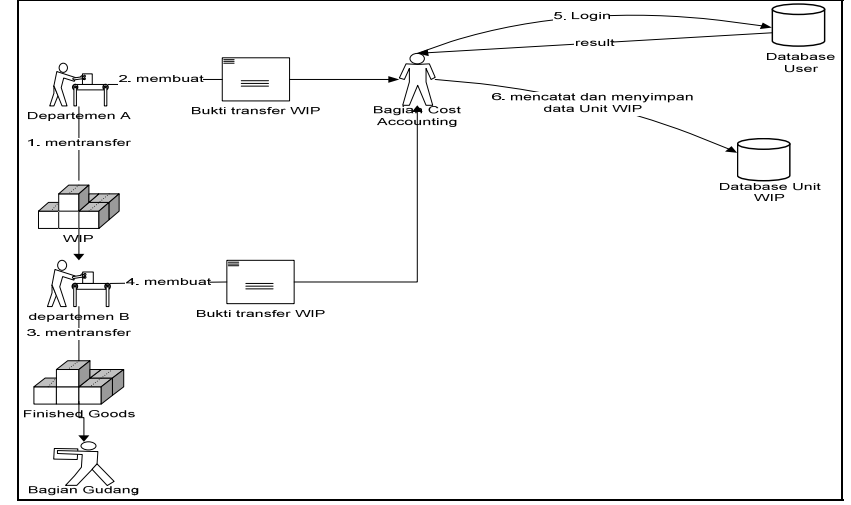

Gambar 9 Rich Picture pencatatan transfer unit WIP (work in process)

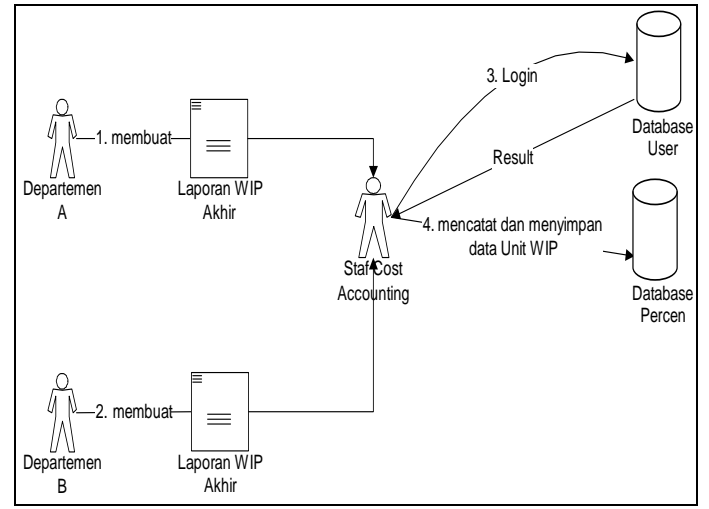

Gambar 10 Rich Picture Pencatatan unit WIP akhir

\section{UML Class Diagram}

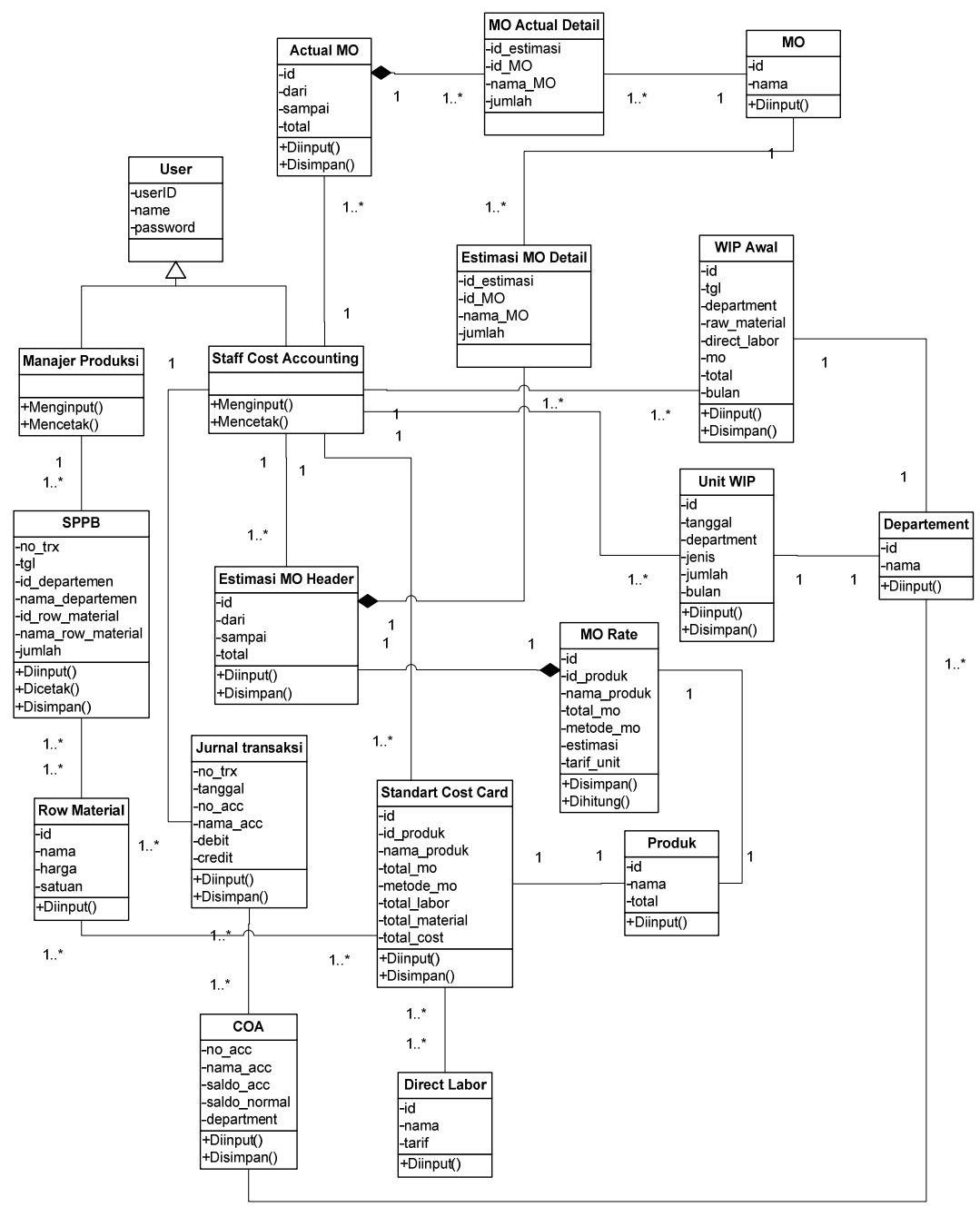

Gambar 11 UML Class Diagram 


\section{Rancangan Formulir}

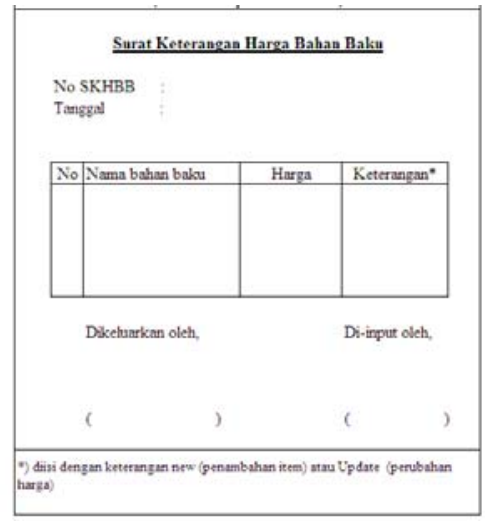

Gambar 12 Rancangan Formulir Surat Keterangan Harga Bahan Baku

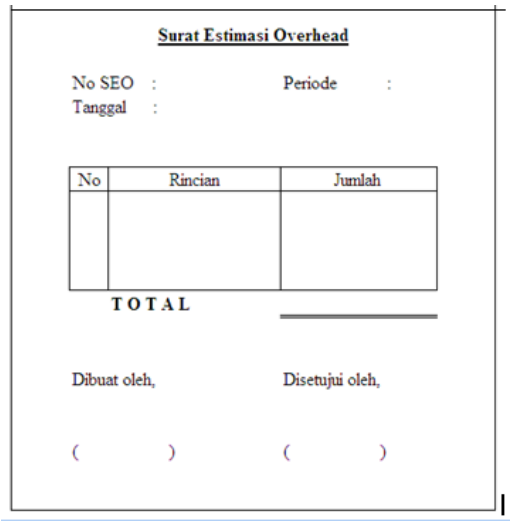

Gambar 13 Rancangan Formulir Surat Estimasi Overhead

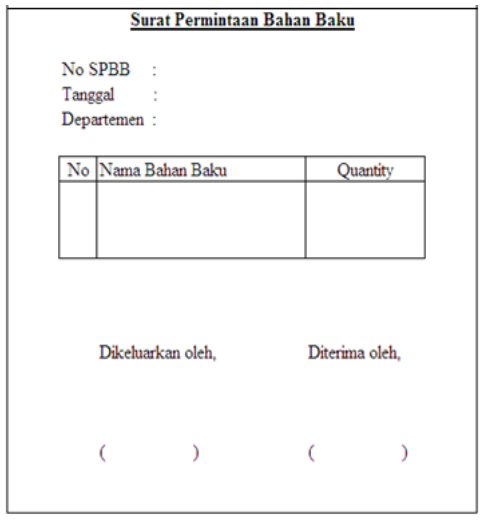

Gambar 14 Rancangan Formulir Surat Permintaan Bahan Baku

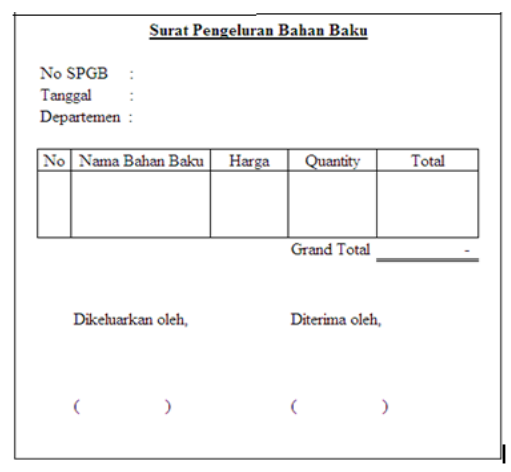

Gambar 15 Rancangan Formulir Surat Pengeluaran Bahan Baku

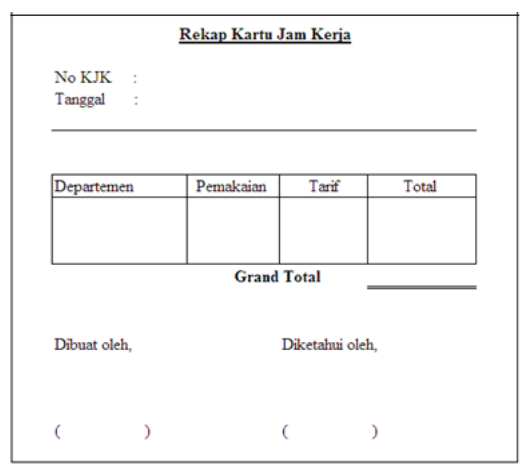

Gambar 16 Rancangan Formulir Rekap Kartu Jam Kerja

\section{Rancangan Laporan}

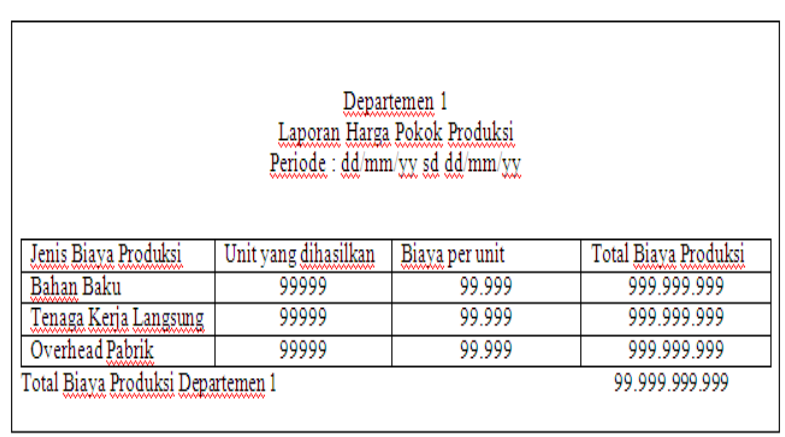

Gambar 17 Rancangan Laporan Harga Pokok Produksi Departemen 1

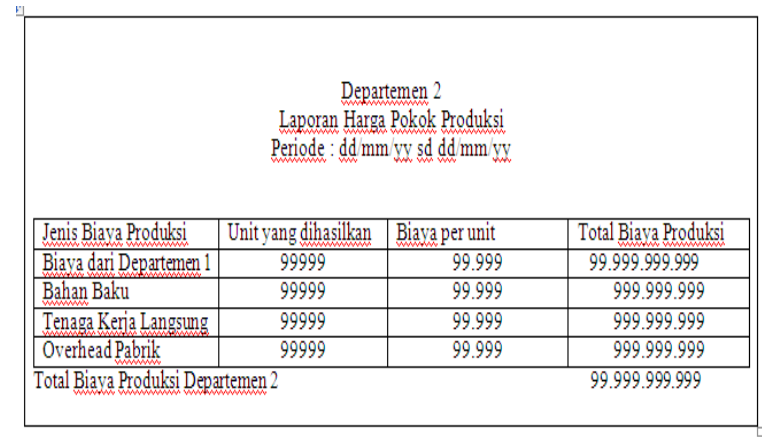

Gambar 18 Rancangan Laporan

Harga Pokok Produksi Departemen 2 


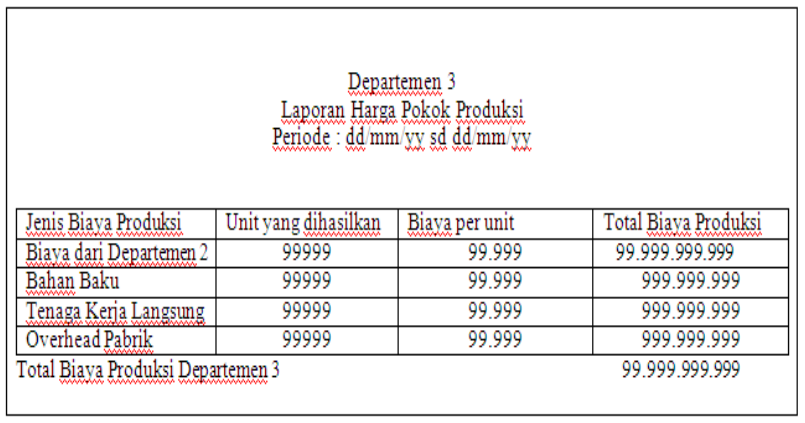

Gambar 19 Rancangan Laporan Harga Pokok Produksi Departemen 3

\section{Rancangan Layar}

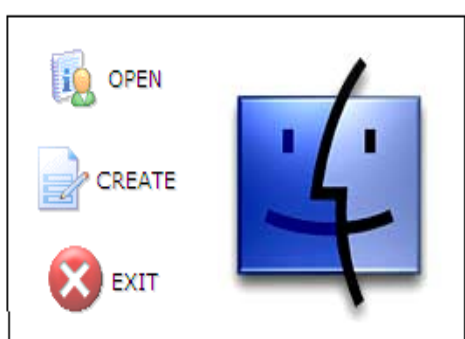

Gambar 20 Layar Awal Program

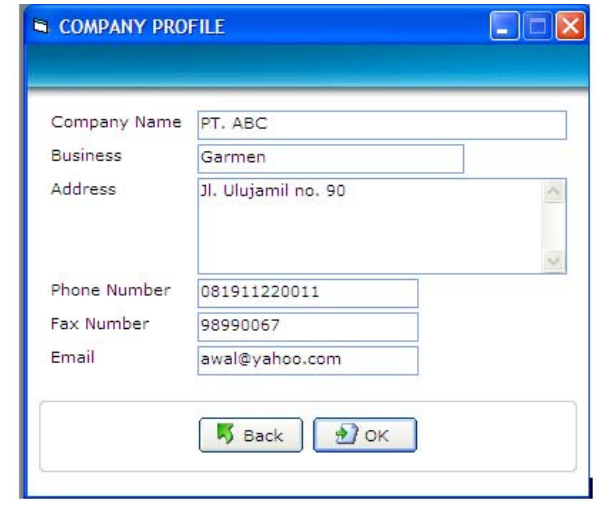

Gambar 21 Layar Input Profile

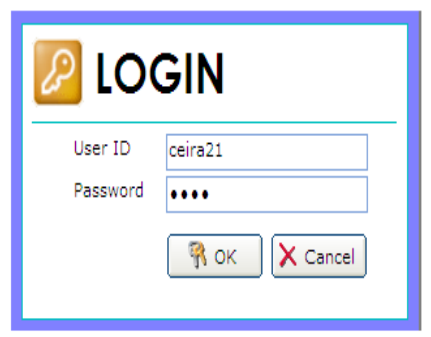

Gambar 22 Layar Login

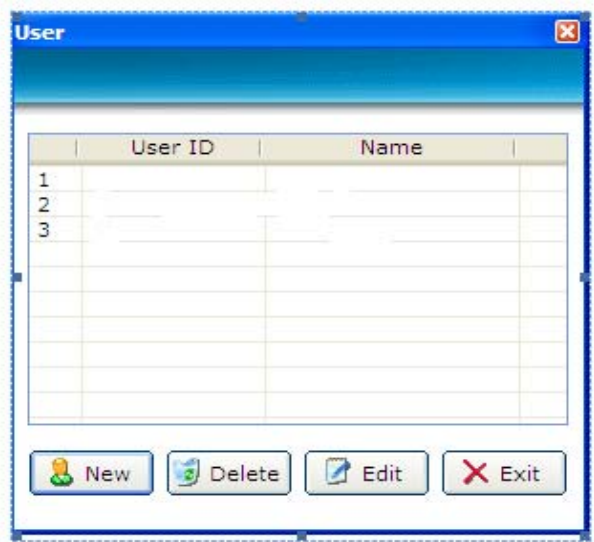

Gambar 23 Layar User

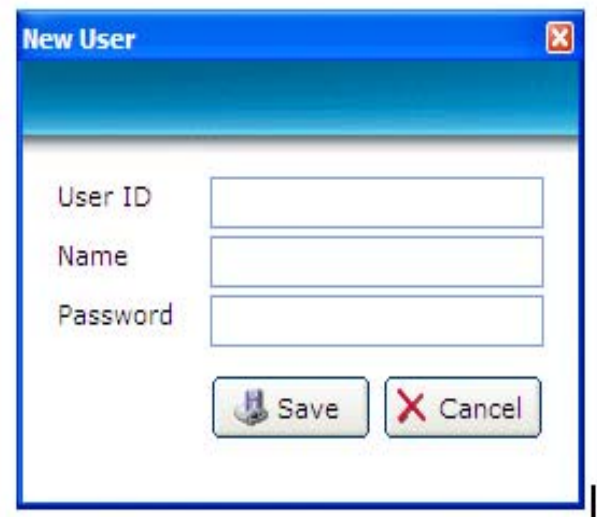

Gambar 24 Layar Input User 


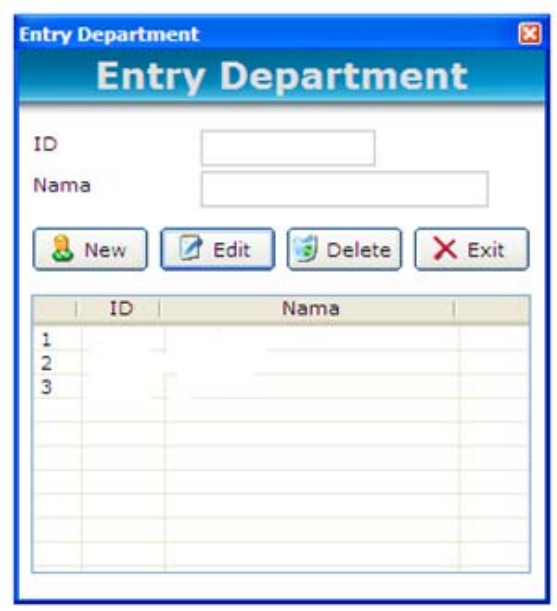

Gambar 25 Layar Entry Departement

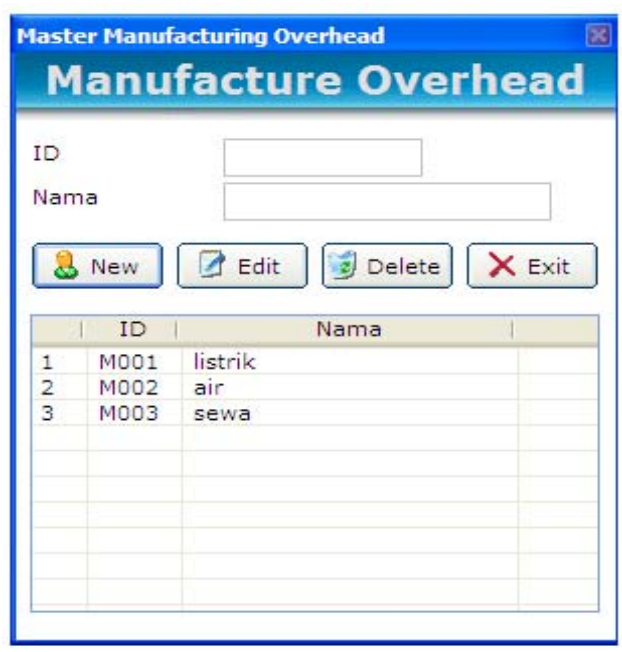

Gambar 27 Layar Manufacture Overhead

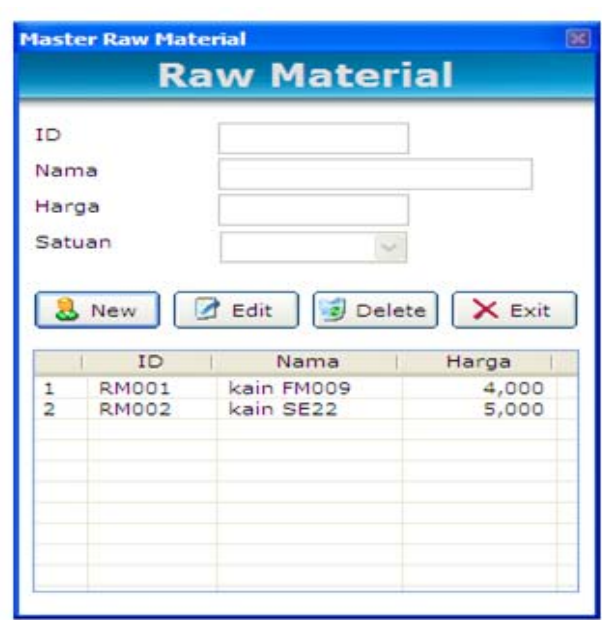

Gambar 29 Layar Raw Material

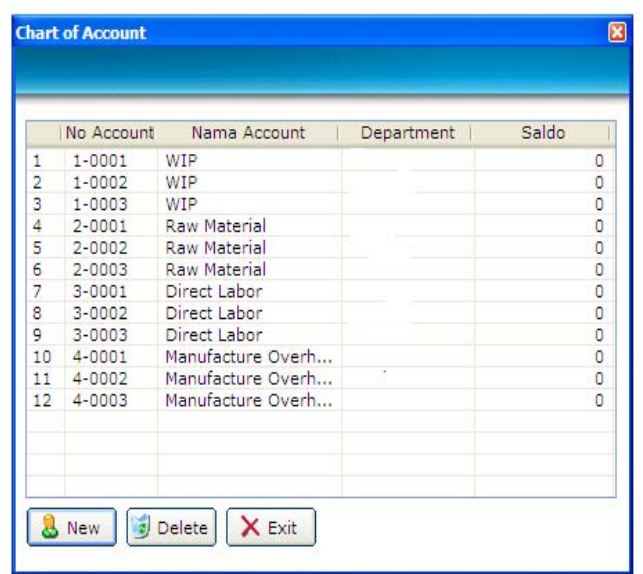

Gambar 26 Layar Chart of Account

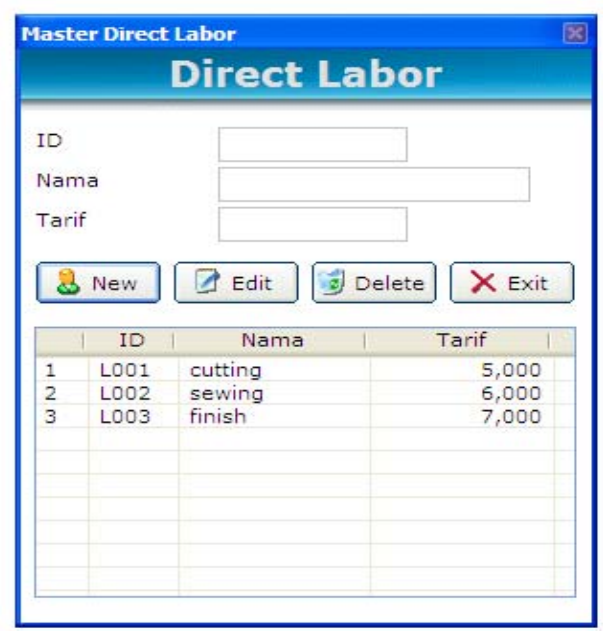

Gambar 28 Layar Direct Labor

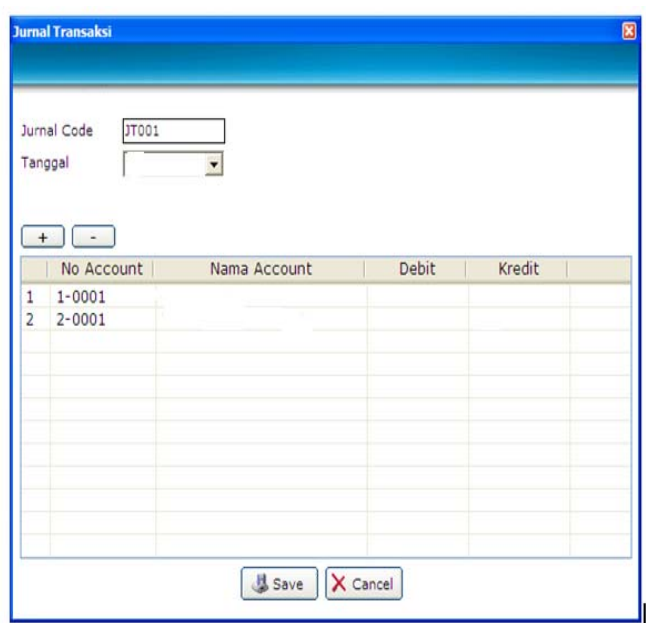

Gambar 30 Layar Jurnal Transaksi 


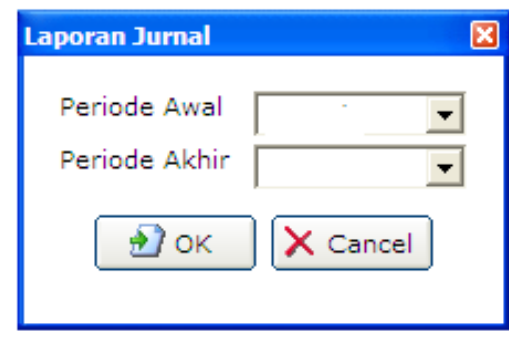

Gambar 31 Layar Jurnal Transaksi

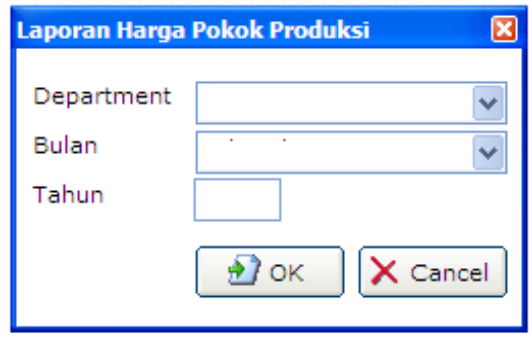

Gambar 32 Layar Laporan Harga Pokok Produksi

\section{Database}

Database yang dihasilkan dari penelitian ini adalah: (1) COA (Cart of Account). (2) Departemen. (3) Tenaga Kerja Langsung (Direct Labor). (3) Tarif Manufacturing Overhead. (4) Master Produk. (5) Master Bahan Baku. (6) Estimasi Manufacturing Overhead. (7) Actual Overhead Pabrik. (8) Master Profile. (9) Master User. (6) Tr_SPBB

\section{SIMPULAN}

Berdasarkan hasil penelitian, maka UKM perlu melakukan pencatatan dan perhitungan biayabiaya dan membuat laporan harga pokok produksi. UKM perlu mengklasifikasikan biaya-biaya yang terjadi dalam proses produksinya sesuai dengan komponen biaya produksi dan memantau komponenkomponen biaya produksi yang terjadi, sehingga mereka tidak mengetahui adanya peningkatan biayabiaya yang terjadi. UKM belum memiliki laporan varians yang merupakan laporan akan selisih dari biaya aktual yang terjadi dengan anggaran biaya yang telah ditetapkan.

Sebaiknya UKM menggunakan aplikasi yang terkomputerisasi terkait proses produksi sehingga laporan harga pokok produksi yang dihasilkan akan lebih akurat. UKM juga diharapkan dapat memperhatikan pengklasifikasian unsur-unsur biaya yang terjadi dalam proses produksinya. UKM yang bergerak di bidang mass production dengan adanya sistem yang terkomputerisasi dapat melakukan perhitungan biaya produksi dengan cepat dan efisien. Perlu adanya pengendalian biaya oleh manajemen dengan menyelidiki deviasi (perbedaan) pelaksanaan standar yang besar dan kemudian mengambil tindakan koreksi.

\section{DAFTAR PUSTAKA}

Boggs, R. A. (1987) Implications of Formal Production Information System for Production Management, 08(4), International Journal of Operations \& Production Management.

Heizer, J., Render, B. (2006). Operations Management jilid 1. Terjemahan Setyoningsih D \& Almahdy I. Jakarta: Salemba Empat

Horngren, C. T., Datar, S. M., Rajan, M. V. (2012). Cost Accounting A Managerial Emphasis. New York: Prentice Hall.

Jogiyanto, H. M. (2005) Analisis dan Desain Sistem Informasi: Pendekatan Terstruktur Teori dan Praktik Aplikasi Bisnis. Yogyakarta: Penerbit Andi. 
Meyer, A. D., Ferdows, K. (1990). Influence of Manufacturing Improvement Programmes On Performance, 10(2). International Journal of Operations \& Production Management.

O’Brien, J. A.. (2005). Pengantar Sistem Informasi: Perspektif Bisnis dan Manajerial. (Edisi ke-12). Terjemahan. Jakarta: Salemba Empat.

Romney, M. B., Steinbart, P. J. (2006). Accounting Information Systems. (10 th Edition). Pearson Prentice Hall

Sedgewick, D. (1992). Productivity control. Work Study Journal 41(7): 8-10.

Whitten, J., Bentley, L., Dittman, K. (2009). System Analysis and Design Method. (7 ${ }^{\text {th }}$ Edition). Boston: McGraw-Hill 